\title{
BEKAL UNTUK BERDAKWAH DI PEDALAMAN
}

\author{
Amin Hasan
}

\begin{abstract}
ABSTRAK
Ummat Islam dewasa ini, adalah ummat yang keadaannya paling tidak menguntungkan. Terlepas kenyataan bahwa dialah ummat dengan jumlah terbanyak, yang berarti paling besar pula sumber daya manusianya, serta satu-satunya ummat yang memiliki sumber atau jalan hidup yang paling tidak goyah dibanding dengan ummatummat lainnya di dunia ini. Namun kenyataannya, dialah ummat yang terpecah-pecah ke dalam negara-negara dan daerah-daerah yang tidak saling cocok, ditambah dengan sekat-sekat yang tercipta oleh berbagai mazhab, golongan serta aliran-aliran, dan diramaikan dengan beragamnya organisasi-organisasi dakwah Islam yang menjadikannya sebagai ummat yang tak mampu mempertahankan diri dari serangan musuh, ummat yang malah menjadi mangsa semua orang. Alih-alih menjadi ummat yang kuat, yang mampu memproduksi sendiri apa yang dibutuhkan dan diperlukan, ia malah menjadi ummat yang menghadapi berbagai problem kemanusiaan seperti kemiskinan, kelaparan, penyakit, kebodohan, permusuhan, kebencian, moralitas dan lain sebagainya.

Melihat kondisi seperti ini, maka sangat bijak dan tepat untuk mengobarkan api semangat dakwah, dimulai dari pedalaman dan dari hal-hal mendasar ummat, dengan semangat juang berlandaskan pada diktum llahi yang mengatakan bahwa: "Sesungguhnya Allah tidak akan mengubah kondisi suatu kaum kecuali mereka mau mengubah kondisi diri mereka sendiri." (QS. Ar-Ra'd [13]:11)
\end{abstract}

Kata Kunci: Berdakwah, Perjuangan, Pengorbanan, Ikhlas, Niat yang Lurus, Peradaban, Tantangan Pemikiran Islam

\section{A. Pendahuluan}

Sudah mafhum bahwa saat ini tantangan berdakwah semakin tidak mudah. Menguasai materi dan metode dakwah saja tidak cukup. Sebab, kita hidup di zaman modern, yaitu zaman yang serba praktis dan cepat, zaman dimana timbunan informasi menghujani pikiran, perasaan dan hati kita. Saking banyaknya informasi yang didengar dan diterima, kita kemudian menjadi ragu dan bahkan tidak tahu lagi bagaimana harus beragama dan mengamalkan agama secara benar.

Di sekitar kita didapati ada berbagai macam model ber-Islam. Ada Islam menurut mazhab dan kemudian 
membentuk sekat yang kuat diantara perbedaan mazhab. Kemudian ada Islam menurut organisasi masyarakat/ormas dakwah Islam, seperti Nahdlatul Ulama/NU, Muhammadiyah, Persis, PKS, Hidayatullah, Jama'ah Tabligh/Islam Kuba, dan lain-lain, yang juga membentuk sekat yang kuat diantara perbedaan masing-masing ormas. Ada pula model ber-Islam menurut pemikir modernis, dan ada pula Islam menurut kiai Salafi. Berbagai macam model ber-Islam tersebut kemudian ditambah lagi dengan munculnya berbagai jenis Islam, ada Islam Moderat, Islam Inklusif, Islam Radikal, Islam Fundamental, Islam Abangan, Islam Nusantara, sampai pada munculnya Islam Gafatar.

Ternyata tidak cukup sampai di situ. Beragamnya model ber-Islam di atas kemudian diramaikan dengan terus bermunculannya ideologi-ideologi, ajaran-ajaran maupun pahampaham/isme-isme baru, seperti liberalisme, pluralisme, sekularisme, skeptisisme, relativisme, multikulturalisme, feminisme/gender, rasionalisme, empirisme, pragmatisme, humanisme, dan lain sebagainya, ${ }^{1}$ yang

\footnotetext{
${ }^{1}$ Baca Hamid Fahmy Zarkasyi, Misykat; Refleksi tentang Westernisasi, Liberalisasi, dan Islam (Jakarta: INSISTS \& MIUMI, 2012). Baca juga Hamid Fahmy Zarkasyi, Liberalisasi Pemikiran Islam (Gerakan bersama Missionaris,
}

semuanya semakin mempertebal sekatsekat jurang pemisah diantara ummat, yang semakin membuat kita bingung dan bahkan tidak tau lagi seperti apa dan bagaimana mengamalkan agama secara benar. Tegasnya, problema ummat tidak sederhana, tantangan berdakwah tidak mudah, ia sangat kompleks.

Berdasarkan uraian di atas, maka makalah ini akan menguraikan tantangan berdakwah yang menjadi "hutan belantara" saat ini. Artinya, makalah ini diharapkan mampu memberi pencerahan mengenai tantangan dalam berdakwah dalam konteks dunia modern seperti saat ini sebagai bekal untuk siap terjun berdakwah di pedalaman. Jadi, makalah ini tidak membahas persoalan geografis di pedalaman. Di akhir tulisan juga akan diuraikan, bahwa mempersiapkan sebuah peradaban adalah dimulai dari pedalaman.

\section{B. Totalitas dalam Berdakwah}

Islam harus didakwahkan dengan bijaksana, nasehat yang baik serta dengan sanggahan yang santun. Dakwah Islam bukan dengan pedang terhunus. Namun, Muslim tidak boleh

Orientalis dan Kolonialis) (Gontor-Ponorogo: CIOS, 2008). Baca juga Muhammad 'Imarah, Perang Terminologi Islam Versus Barat, diterjemahkan dari Ma'rakatul Mushthalahat baina al-Gharbi wal Islami, oleh Musthalah Maufur (Jakarta: Rabbani Press, 1998). 
bersabar jika Muslim diserang dan dibunuh. Dakwah Islam yang berbau peperangan harus difahami sebagai upaya pembelaan. Dakwah Islam adalah "pembebasan", bukan penaklukan atau peperangan 'harb'. ${ }^{2}$ Totalitas dalam berdakwah adalah persoalan perjuangan dan pengorbanan. Siap berdakwah berarti siap memberi dan mendahulukan kewajiban daripada menuntut hakhaknya. Maka dalam hal ini, sangat penting untuk menata dan meluruskan niat. ${ }^{3}$ Agar tidak sia-sia perjuangan dan pengorbanan yang dilakukan, maka sejak awal harus ditanamkan niat berjuang dan berkorban demi ummat karena Allah SWT, bukan karena ingin mencari kehormatan, penghargaan, apalagi kekayaan. Apalah artinya suatu amal atau pekerjaan apabila dilakukan dengan niat yang salah. Niat yang benar dan lurus inilah yang akan menjaga keistiqomah-an seseorang dalam

\footnotetext{
2 Watak Islam yang membebaskan juga diakui oleh Napoleon Bonaparte. Dalam buku Bonaparte et L'Islam karya Cherfils, menyimpulkan bahwa "mereka membebaskan manusia dari Tuhan-tuhan Palsu, memunahkan banyak berhala, merobohkan kuil orang-orang kafir hanya dalam waktu 15 tahun, padahal pengikut Musa dan Yesus memerlukan waktu 15 abad". Selengkapnya silahkan baca Hamid Fahmy Zarkasyi, "Dakwah", dalam ISLAMIA: Jurnal Pemikiran dan Peradaban Islam, Vol. VII, No. 2, 2012, hal. 118-120.

3 "Niat seorang mukmin lebih baik dari amalnya." (HR. At-Tirmidzi)
}

berdakwah dan menjadikannya bernilai ibadah di sisi Allah SWT. ${ }^{4}$

Ketidakpahaman terhadap nilainilai perjuangan dan pengorbanan dapat berakibat buruk terhadap dakwah itu sendiri, karena bisa jadi akan salah dalam melaksanakan visi dan misi, arah serta tujuan dari dakwah yang dilakukannya. Oleh karena itu, seorang da'i harus memiliki ruh/jiwa pendakwah. Ruh/jiwa pendakwah ini adalah lebih penting dari materi dan metode dakwah, bahkan ia lebih penting daripada da'i itu sendiri. Ruh/jiwa pendakwah ini muncul karena "rasa" ${ }^{5}$ keterpanggilan, yaitu hati nuraninya terpanggil untuk berdakwah. Rasa keterpanggilan inilah yang akan meluruskan niatnya dalam berdakwah. Rasa keterpanggilan ini pula yang akan menjadikannya ikhlas untuk berjuang dan berkorban dalam berdakwah. la tidak akan mengharapkan imbalan apaapa. Semuanya ia lakukan hanya karena Allah SWT. Ikhlas yang dimaksud di sini

\footnotetext{
4 Abdullah Syukri Zarkasyi, Bekal untuk Pemimpin, Pengalaman Memimpin Gontor (Gontor-Ponorogo: Trimurti Press, 2011), hal. 126-129.

${ }^{5}$ Rasa (zauq), menurut Imam Al-Ghazali, adalah seperti melihat dan mengambil dengan tangan dan tidak di dapat kecuali pada jalan kaum sufi. Baca Abu Hamid Al-Ghazali, Al-Munqidz min al-Dlalal wa ma'a Kimiya al-Sa'adah wa alQawa'id al-'Asyrah wa al-Adab fi al-Din (Beirut: Al-Maktabah Al-Sya'biyah, t.t.). Baca juga Abu Hamid Al-Ghazali, Penyelamat Jalan Sesat, diterjemahkan dari Al-Munqidz min alDlalal, oleh Nasib Musthafa (Jakarta: Cendekia Sentra Muslim, 2002).
} 
adalah ikhlas yang dinamis dan produktif, yang diwujudkan dengan berbagai gerakan dan kegiatan, yang dimotivasi dengan penuh kesungguhan: kerja keras, berfikir keras, bersabar keras, dan berdo'a keras. Inilah ikhlas yang sesungguhnya. Ikhlas yang melahirkan cita-cita besar dan karya-karya yang bermanfaat untuk masyarakat, agama dan ummat. ${ }^{6}$

Sebaliknya, apabila seorang da'i tidak mempunyai ruh/jiwa pendakwah, maka tidak ada lagi keikhlasan dalam dakwahnya, niatnya tidak akan lurus, dakwah yang dilakukannya pun akan terasa "hambar" sehingga tidak ada lagi nilai-nilai perjuangan dan pengorbanan di dalamnya. Apa yang dilakukannya akan bernilai pragmatis dan penuh hitunghitungan. Semuanya akan dirasionalkan dan harus tampak jelas secara empiris/inderawi ${ }^{7}$ keuntungan apa yang akan ia diperoleh dari dakwah yang dilakukannya. Jika memiliki uang $\mathrm{Rp}$.

\footnotetext{
${ }^{6}$ Ikhlas, tidak saja merupakan prasyarat diterima atau tidaknya amal perbuatan manusia, tapi ia juga menjadi syarat mutlak bagi kemajuan dan perkembangan usaha apapun. Abdullah Syukri Zarkasyi, Op.cit., hal. 46-53.

7 Wacana mengenai rasionalisme, empirisme dan hal-hal yang berhubungan dengannya, silahkan baca Muhammad Muslih, Filsafat Ilmu: Kajian atas Asumsi Dasar Paradigma dan Kerangka Teori Ilmu Pengetahuan (Yogyakarta: Belukar, 2008). Baca juga Jujun S. Suriasumantri, Filsafat Ilmu: Sebuah Pengantar Populer (Jakarta: Pustaka Sinar Harapan, 2009). Baca juga F. Budi Hardiman, Filsafat Modern: Dari Machiavelli sampai Nietzsche (Jakarta: Gramedia, 2004)
}

50.000 ,- di dalam saku, uang ini akan terasa kecil sekali nominalnya jika dibawa ke Mall, akan tetapi nominal 50.000,- tersebut akan terasa besar sekali jika di sedekahkan atau disumbangkan ke masjid. Ini adalah contoh sederhana mengenai pola pikir dan perilaku yang serba rasional dan empiris-pragmatis tersebut. Semuanya akan dinilai dan diperhitungkan secara matematis.

Jika sudah demikian, maka nilainilai dakwah yang dilakukannya akan terhijab oleh standar-standar rasional dan empiris-pragmatis tersebut. Akibatnya, ia pun tidak bisa me-"rasa"-kan ruh/jiwa seorang pendakwah, apalagi untuk ia rumuskan. Oleh karena itu, untuk bisa berdakwah secara totalitas, ikhlas serta memiliki niat yang lurus dalam berjuang dan berkorban, serta memiliki rasa keterpanggilan dan ruh/jiwa seorang pendakwah adalah tergantung pada seberapa jauh ia mampu merobohkan standar-standar rasional dan nilai-nilai empiris-pragmatis yang ia ciptakan sendiri itu. Orang yang telah mampu merobohkan standar-standar rasional dan nilai-nilai empiris-pragmatis tersebut, dalam perjalanan dakwahnya akan merasakan kenikmatan dan keasyikan dalam berdakwah, tidak perduli seberapa besar rintangan dan kesulitan yang dihadapi, ia akan dapat melaluinya 
dengan ringan dan mudah, karena ia telah mampu menangkap dan me-rasakan ruh/jiwa seorang pendakwah.

Lantas, sudahkah kita siap untuk berdakwah dan mau berjuang serta berkorban fikiran, tenaga, harta dan perasaan untuk ummat karena Allah SWT? ${ }^{8}$

\section{Tantangan Berdakwah di Pedalaman}

Dakwah Islam adalah diperuntukkan kepada ummat Islam itu sendiri, yaitu sebagai upaya membentengi keyakinan ummat Islam serta untuk meningkatkan keimanan mereka sehingga semakin kokoh keimanannya menjadi seorang Muslim. Di sini tampak jelas bahwa dakwah Islam dilakukan tidak hanya diperuntukkan bagi penganut agama non-Islam sebagaimana halnya kristenisasi, yang memang diperuntukkan hanya untuk penganut agama non-Kristen. Misi kristenisasi, sebagaimana yang ditegaskan oleh Zwemer ${ }^{9}$ pada Konferensi Misionaris, pada tahun 1935, di Kota Yerussalem, yaitu: "Misi utama kita sebagai orang Kristen bukan menghancurkan kaum Muslimin, namun

8 Tidak ada orang yang kaya karena pelit, dan miskin karena dermawan. Lebih lanjut silahkan baca Abdullah Syukri Zarkasyi, Op.cit.

9 Samuel Marunus Zwemer (1867-1952) ialah seorang orientalis yang menjabat direktur organisasi misionaris. Pendiri Jurnal The Muslim World ini adalah misionaris yang paling terkenal dari abad kedua puluh . mengeluarkan seorang Muslim dari Islam, agar jadi orang Muslim yang tidak berakhlak."10

Sementara itu, dari sisi lahan dakwah, jika selama ini para da'i lebih tertarik berdakwah di perkotaan, maka sudah saatnya para da'i "melirik" dan menggiatkan aktivitas dakwahnya di pedalaman. Secara karakteristik masyarakatnya, tentu tidak sama dengan masyarakat perkotaan, sehingga "model" berdakwahnya pun menjadi tidak sama pula. Masyarakat pedalaman memiliki cara pandang dan pemikiran yang "unik" dibanding masyarakat urban (perkotaan). Sehingga, di pedalaman, para da'i dituntut tidak hanya cukup datang dan berceramah di depan masyarakat sebagaimana yang mungkin biasa dilakukan pada masyarakat perkotaan. Di pedalaman, para da'i harus mampu menyentuh sisi "perasaan" mereka. Artinya, dakwah dikatakan berhasil jika masyarakatnya merasa "terangkul" secara psikologis.

Oleh karena itu, butuh pendekatan khusus dalam berdakwah pada masyarakat pedalaman. Misalnya, ikut menyelesaikan problem yang mereka alami, bisa dengan memberikan gagasan-gagasan yang bersifat solutif, jika memang masalahnya bisa

\footnotetext{
${ }^{10}$ Ali Gharisah, Wajah Dunia Islam Kontemporer (Puskata Al-Kautsar, 1989), hal. 41.
} 
diselesaikan dengan cara seperti itu. Atau, mungkin dengan melakukan pendekatan secara materil, jika memang masalahnya hanya bisa diatasi dengan hal yang bersifat materil. Selain itu, pendekatan dakwah kepada masyarakat pedalaman juga bisa dilakukan dengan cara pengobatan atau menyembuhkan yang sakit, baik secara medis maupun non-medis, seperti bekam, ruqyah, dan lain sebagainya. Intinya, para da'i yang terjun ke pedalaman dituntut tidak cukup hanya memiliki pengetahuan keagamaan yang tinggi, tetapi mereka juga dituntut untuk memiliki pengetahuan dan kemampuan extra yang juga bisa menjadi cara yang tepat dan efektif untuk berdakwah kepada masyarakat. Hal ini menjadi tantangan tersendiri bagi para da'i yang akan terjun ke pedalaman.

Di samping itu, seorang da'i juga harus 'supel' dan memiliki kemampuan berkomunikasi dan bersosialisasi yang baik. Ia harus bisa mendekati dan mimbina hubungan baik dengan masyarakat. Untuk bisa mengerti dan memahami karakter masyarakat pedalaman, maka seorang da'i tidak hanya datang sekali dua kali untuk memberikan dakwahnya kepada masyarakat. la harus menetap dan tinggal bersama masyarakat untuk waktu yang cukup lama. Di sinilah, yang juga menjadi salah satu tantangan berdakwah di pedalaman, dimana masih kurangnya da'i yang rela berkorban secara totalitas ${ }^{11}$, terjun langsung ke tengahtengah masyarakat dan 'berjibaku' menyebarkan agama Islam, membentengi dan memperkokoh akidah ummat di pedalaman dalam waktu yang lama.

Pesan Nabi Muhammad SAW sebelum mengeluarkan da'i-da'i keluar dari jazirah Arab: "Pergilah dan janganlah kaliah seperti utusan-utusan Isa bin Maryam yang hanya pergi kepada orang-orang yang terdekat saja dan melupakan negeri yang jauh-jauh" (riwayat Ibn Sa'd). Kalimat "negeri yang jauh-jauh" bermakna bahwa dakwah Islam itu harus diperluas dan disebarkan sampai ke tempat-tempat yang jauh. Dakwah harus keluar melintas jazirah, sebab Islam bukan agama untuk bangsa di jazirah Arab itu saja. Islam adalah rahmat bagi semesta alam. ${ }^{12}$ Hal ini menjadi PR kita bersama, bahwa dakwah itu harus diperluas dan disebar sampai ke tempat-tempat yang jauh, sampai ke pelosok-pelosok pedalaman. Tidak heran jika selama ini dakwah Islam masih berada di bawah bayang-bayang kristenisasi, itu karena dakwah Islam

\footnotetext{
${ }^{11}$ Mengenai totalitas tata sosial Islam, aktivitasaktivitasnya serta mengenai ummat secara keseluruhan, silahkan baca Isma'il Raji AlFaruqi, Tauhid (Bandung: Pustaka, 1988).

12 (QS. Al-Anbiya [21]: 107). Baca juga Hamid Fahmy Zarkasyi, Op.cit., 2012, hal. 118-120.
} 
kurang mampu menyentuh lapisan masyarakat di polosok-pelosok pedalaman, apalagi untuk waktu yang lama. Berbeda halnya dengan kristenisasi. Kristenisasi, selain mereka lakukan di perkotaan; kepada para korban bencana alam, seperti sunami, gunung meletus; pada momen-momen tertentu, seperti terungkapnya kasus dugaan kristenisasi pada event Car Free Day; kader-kader mereka juga rela berkorban dengan menetap di pelosokpelosok masyarakat pedalaman dalam waktu yang lama, kemudian bergaul, membaur dan mendekati para warga, bahkan mereka tidak segan-segan membantu masyarakat dalam bentuk materi. ${ }^{13}$

Ini juga menjadi tantangan tersendiri bagi para da'i khususnya dan ummat Islam pada umumnya, bahwa gerakan kristenisasi tersebut dilakukan secara massive dan terstruktur terhadap ummat Islam. Di sisi lain, sebagaimana yang kita sadari bersama bahwa, sekarang ini kita hidup di zaman modern, zaman yang serba up date, serba canggih, serba cepat, dinamis dan praktis. Kita bisa saksikan, misalnya, bagaimana suatu informasi begitu cepat

\footnotetext{
13 Untuk lebih lengkapnya mengenai kristenisasi dan sejarahnya, silahkan baca Muhammad 'Imarah, Op.cit., hal. 89-93. Baca juga mengenai Misionaris sebagai agen liberalisasi dalam Hamid Fahmy Zarkasyi, Op.cit., 2008, hal. 44-54.
}

tersebar dan sampai kepada kita. Bahkan dalam hitungan detik, kita bisa menyaksikan suatu kejadian/peristiwa yang terjadi di negara lain, yang berasal dari negara nun jauh di sana. Seolaholah tidak ada lagi jarak tempat dan sekat waktu di dunia ini.

Dengan demikian, arus globalisasi ${ }^{14}$ yang sedang berlangsung dewasa ini menjadi suatu kenyataan yang tidak dapat ditolak, tapi tidak berarti harus diterima. Globalisasi perlu disadari adanya, difahami dan kemudian direspon secara cepat dan tepat. Globalisasi merupakan suatu proses dimana bangsa-bangsa terkondisikan dalam situasi untuk menerima kultur, tradisi, konsep, sistim dan nilai-nilai yang dianggap global/universal. Jadi, perlu disadari bahwa globalisasi juga bermakna suatu program agar bangsabangsa yang lemah menerima nilai-nilai dari bangsa yang kuat, dalam hal ini adalah Barat. Di sini globalisasi menjadi berarti Westernisasi. ${ }^{15}$

\footnotetext{
${ }^{14}$ Baca Amer al Roubaie, "Globalisasi dan Posisi Peradaban Islam", dalam ISLAMIA: Jurnal Pemikiran dan Peradaban Islam, Thn. 1, No. 4, 2005, hal. 10-26.

15 Dalam sejarah peradaban ummat manusia, situasi dimana bangsa yang kuat mempengaruhi bangsa yang lemah, atau yang lemah meminjam ide, konsep dan tehnik dari yang kuat adalah sesuatu yang wajar dan alami. Namun, yang tidak wajar adalah ketika bangsa-bangsa yang merasa kuat itu berusaha untuk memasukkan ide, nilai, pandangan hidup dan kulturnya ke dalam pikiran bangsa lain dengan cara-cara yang tidak alami. Inilah yang terjadi dalam
} 
Ini juga menjadi tantangan, yang tidak kalah pentingnya, bagi para da'i di pedalaman maupun para da'i pada umumnya. Sebab, selama ini kita berfikir bahwa hanya masyarakat perkotaan lah yang terpengaruh langsung dan menerima dampak dari Westernisasi. Sedangkan masyarakat pedalaman masih hidup dengan damai dan tenteram, jauh dari hiruk-pikuk dan 'glamor' serta kerasnya hidup, yang hidup dengan kultur dan nilai-nilainya yang masih kental, seperti kesederhanaan, ramah-tamah, sopansantun, tolong-menolong, gotong-royong, memegang adat-istiadat, kebersamaan, kekeluargaan, religuisitas keberagamaan yang tinggi, dan lain sebagainya. Namun, dengan arus globalisasi dan informasi yang begitu cepat saat ini, menjadikan masyarakat pedalaman tidak ada bedanya dengan masyarakat perkotaan. Masyarakat pedalaman saat ini telah "akrab" dengan teknologi, fashion/mode, gaya hidup, pandangan hidup, perilaku dan pola pikir modern ala-Barat.

Artinya,

kehidupan sebagaimana yang ada pada masyarakat perkotaan, saat ini juga telah 'booming' pada masyarakat pedalaman. Jadi,

proses Westernisasi. Untuk penjelasan lebih lanjut silahkan baca Hamid Fahmy Zarkasyi, Op.cit., 2008. Baca juga Adian Husaini, Wajah Peradaban Barat: Dari Hegemoni Kristen ke Dominasi Sekuler-Liberal (Jakarta: Gema Insani Press, 2005), hal. 16-27. jangan heran jika kita menjumpai masyarakat pedalaman menggunakan gadget, laptop, dan berbagai teknologi canggih lainnya. Mereka sekarang juga akrab dengan berbagai media sosial seperti facebook, whatsapp, twitter, line, instagram, dan lain-lain. Selain itu, jangan heran juga jika menemukan anakanak pedalaman dengan mode rambut, fashion pakaian, asesoris penampilan dan gaya hidup seperti anak-anak kota, atau bahkan anak-anak pedalaman itu terlihat lebih "kota" daripada anak-anak perkotaan itu sendiri.

Ternyata tidak cukup sampai di situ. Perilaku, pandangan hidup dan pola pikir yang ke Barat-baratan juga diadopsi oleh masyarakat pedalaman. Oleh karena itu, kita saksikan sekarang ini, dengan mudahnya konsep-konsep, gagasan serta ide-ide "asing" masuk dalam kehidupan mereka. Sehingga dewasa ini sering kita dengar dan temukan ideologi-ideologi, paham-paham maupun ajaran-ajaran baru muncul dalam kehidupan masyarakat pedalaman. Sebut saja di antaranya adalah munculnya Islam Gafatar, yang baru-baru ini cukup menyita perhatian masyarakat Indonesia, yang mana sebagian besar sasarannya adalah masyarakat kelas menengah ke bawah/masyarakat pedalaman. 
Tegasnya, tantangan seorang da'i dalam berdakwah di pedalaman semakin tidak mudah. Zaman berkembang dan berubah dengan pesat dan cepat. Problema yang dihadapi ummat semakin kompleks. Oleh karena itu, seorang da'i dituntut untuk selalu up date perkembangan kekinian. Seorang da'i harus bisa mengetahui dan memahami bagaimana penyerabaran pandangan hidup Barat yang terbungkus rapi dalam arus globalisasi itu terjadi, bagaimana program Westernisasi meng'gurita' sampai ke pedalaman, serta bagaimana proyek liberalisasi secara terstruktur masuk dalam berbagai bidang kehidupan masyarakat, terutamanya yang paling dirasakan oleh ummat Islam adalah liberalisasi pemikiran keagamaan Islam. Seorang da'i harus cepat mengenali semua isu-isu tersebut, kemudian segera melakukan langkahlangkah preventif, merespon serta menjawab persoalan ummat ini dengan cepat.

\section{Membangun Peradaban Dimulai dari Pedalaman}

Pedalaman, adalah tempat yang sejuk dan nyaman. Tempat yang tenteram dan kondusif, dimana banyak potensi bisa diaktifkan dan dikembangkan di dalamnya. Dari sana, seharusnya benih peradaban ummat- peradaban Islam disemai. ${ }^{16}$ Dari sisi pemuda-pemudanya misalnya, merupakan aset ummat dengan sumber daya manusianya yang cukup potensial. Artinya, pola pikir dan perilaku yang masih murni bisa dikembangkan dan dibina menjadi satu kekuatan ummat yang luar biasa. $\mathrm{Di}$ tengah-tengah tantangan liberalisasi pemikiran Islam (ghazwul fikr) ${ }^{17}$ dan hegemoni Baratmodern ${ }^{18}$ saat ini, kiranya sangat tepat dan bijak untuk memulai membangun suatu peradaban ilmu ${ }^{19}$ di pedalaman. Dengan kondisinya yang tenang dan masih murni, kita bersatu untuk berkorban dan berperjuang

16 Baca Hamid Fahmy Zarkasyi, Peradaban Islam: Makna dan Strategi Pembangunannya (Gontor Ponorogo: CIOS, 2010).

17 Mengenai ghazwul fikr, silahkan baca Syamsuddin Arif, Orientalis dan Diabolisme Pemikiran (Jakarta: Gema Insani Press, 2008). Baca juga Hamid Fahmy Zarkasyi, Op.cit., Misykat..., 2012. Baca juga Hamid Fahmy Zarkasyi, Op.cit., 2008). Baca juga Anis Malik Thoha, Tren Pluralisme Agama: Tinjauan Kritis (Jakarta: Perspektif, 2005). Baca juga Syed Muhammad Naquib Al-Attas, Islam and Secularism (Kuala Lumpur: ISTAC, 1993).

18 Dari ujung rambut sampai ujung kaki, masyarakat zaman sekarang merasakan pengaruh peradaban Barat dalam kehidupan sehari-hari. Selengkapnya silahkan baca Adian Husaini, Op.cit., 2005. Baca juga Adian Husaini, Hegemoni Kristen-Barat dalam Studi Islam di Perguruan Tinggi (Jakarta: Gema Insani Press, 2006).

19 Baca Hamid Fahmy Zarkasyi (dkk), Membangun Peradaban dengan Ilmu (Depok: Kalam Indonesia, 2010). Baca juga Sayyed Hossein Nasr, Sains dan Peradaban di Dalam Islam, diterjemahkan dari Science and Civilization in Islam, oleh J. Mahyudin (Bandung: Pustaka, 1977). 
"membangunkan" berbagai potensi terpendam di pedalaman yang sedang "tertidur". Kita kembalikan kejayaan peradaban Islam dimulai dari pedalaman.

Jika melihat kondisi dan potensi yang bisa diaktifkan dan dikembangkan di pedalaman, maka "Masjid" menjadi tempat yang tepat untuk memulai itu semua. Artinya, dari masjid, kita bisa memulai usaha membangun sebuah peradaban. Masjid, di samping sebagai tempat beribadah kepada Allah, sejatinya adalah jiwa peradaban dalam perjalanan panjang sejarah Islam. Dalam jalan panjang dakwah Rasulullah SAW, masjid, meskipun berlantai tanah dan beratapkan pelepah kurma, dari sana benih peradaban Islam disemai. Di sini terlihat dengan jelas bahwa, masjid memegang peranan dan fungsi penting dalam pembentukan peradaban Islam. Sebab, praktek pendidikan pada periode awal Islam dipusatkan di masjid-masjid. Dari masjid kegiatan-kegiatan ummat berpusat, pusat ilmu pengetahuan dan pembinaan akhlak ummat Islam. Hikmah-hikmah dari Rasulullah SAW banyak disampaikan di Masjid. Dan di masjid pula para sahabat menimba ilmu. Masjid menjadi suatu tempat yang integral sebagai pusat keilmuan dan amaliat ummat. ${ }^{20}$

20 Baca Hamid Fahmy Zarkasyi (dkk), Op.cit., Membangun Peradaban..., 2010, hal. iii-iv.
Peran masjid secara umum dalam membangun sebuah peradaban tidak diragukan lagi. Fakta dalam perjalanan sejarah peradaban Islam membuktikan bahwa institusi pendidikan pertama adalah masjid. Dari serambi masjid yang disebut al-Suffah, yang pesertanya disebut Ashab al-Suffah, institusi pendidikan Islam bermula. Di zaman dinasti Umayyah masjid menjadi pusat pendidikan dan pengkajian, di samping lembaga-lembaga pendidikan tradisional lainnya. Di zaman Abbasiyah juga terdapat masjid (jami') sebagai tempat belajar mengajar. Di Mesir, tradisi menjadikan masjid sebagai pusat peradaban selalu terjadi pada setiap dinasti penguasa. Bahkan dalam Islam hampir semua universitas berasal dari sebuah masjid, meskipun terdapat pula beberapa lembaga yang tidak bermula dari masjid. Universitas Al-Azhar di Mesir misalnya, asalnya adalah sebuah masjid, yang ketika menjelma menjadi universitas, tahun 1171, ilmu agama masih dominan dalam kurikulumnya. Universitas Al-Azhar adalah merupakan universitas Islam tertua yang hingga kini terus setia menyertai jatuh bangunnya peradaban Islam. Meski situasi politik

Baca juga Hamid Fahmy Zarkasyi, "Peran Masjid dalam Pendidikan Karakter (Akhlaq)", dalam ISLAMIA: Jurnal Pemikiran dan Peradaban Islam, Vol. IX, No. 1, 2014, hal. 1528. 
dan kekuasaan berubah-ubah, Al-Azhar tetap berjalan sebagai pusat ilmu pengetahuan Islam. ${ }^{21}$

Jadi, mengingat fungsi dan peran masjid yang sangat vital tersebut, maka masjid-masjid yang ada harus dilembagakan secara profesional, sehingga potensi dan perannnya dalam membina jamaah dan masyarakat dapat ditingkatkan. Adapun lembaga-lembaga yang dimaksud sebagai berikut: Pertama, Lembaga Takmir Masjid. Lembaga takmir masjid yang telah ada perlu ditingkatkan lagi peranannya, seperti mengorganisasi seluruh kegiatan masjid, baik yang bersifat formal maupun non-formal. Kedua, Lembaga Majlis Imam dan Khatib Masjid. Lembaga ini harus mampu memfasilitasi masjid dengan imam-imam dan khatib yang soleh, ikhlas dan terpuji akhlaknya, serti tinggi ilmunya yang tikda hanya mengusai baik ilmu agama tetapi juga menguasai ilmu-ilmu umum. Selain itu, tidak hanya menguasai ilmu-ilmu keislaman klasik, tetapi juga ilmu-ilmu modern lengkap dengan penguasaan terhadap isu-isu kontemporer. Ketiga, Lembaga Amil Zakat dan Bait Mal wa

${ }^{21}$ Penjelasan lengkapnya mengenai peran masjid dalam membangun peradaban dunia dan kaitannya dengan universitas, silahkan baca ISLAMIA: Jurnal Pemikiran dan Peradaban Islam, "Wajah Universitas Islam: Antara Islamisasi dan Sekularisasi-Liberalisasi", Vol. III, No. 3, 2008. Baca juga Hamid Fahmy Zarkasyi, Op.cit., 2014, hal. 15-28.
Tanwil (BMT). Setelah kegiatan mengumpulkan, tugas terpenting dari lembaga ini adalah mengelola zakat yang telah terkumpul secara profesional. Intinya adalah untuk mensejahterakan dan mengembangkan kehidupan ummat. Keempat, Lembaga Training. Lembaga training adalah lembaga untuk pelatihanpelatihan berkala tentang berbagai hal dan dalam segala bidang. Kelima, Lembaga Pengkajian Islam. Lembaga pengkajian terdiri dari lembaga keilmuan yang serius untuk peminat dari kalangan terpelajar dan lembaga pengajian untuk tausiyah bapak-bapak dan ibu-ibu yang haus akan tausiyah diniyah. Jadi, untuk lebih efektif, maka lembaga ini harus dilengkapi dengan perpustakaan yang memadai. Tegasnya, Kegiatan intelektual dan aktivitas-aktivitas lainnya yang dilakukan di masjid diharapkan dapat mengoptimalkan potensi masjid sebagai pusat peradaban, sehingga orang-orang tidak melulu melihat masjid sebagai tempat yang "ala kadarnya". ${ }^{22}$

Di pintu gerbang Universitas Granada tertera slogan: "Dunia hanya terdiri dari empat unsur: Pengetahuan Orang Bijak, Keadilan Penguasa, Do'a Orang Shaleh, dan Keberanian

22 Baca Hamid Fahmy Zarkasyi (dkk), Op.cit., Membangun Peradaban..., 2010, hal. iii-iv. Baca juga Hamid Fahmy Zarkasyi, Op.cit., 2014, hal. 25-28. 
Ksatria."23 Artinya, bahwa dunia akan jaya jika dipenuhi oleh orang-orang yang bijak, adil, shaleh dan mujahid. Di tanah Andalusia, Islam pernah mengukir sejarah dunia dengan mencapai masa keemasan selama berabad-abad lamanya. ${ }^{24}$ Warisan ini sangat berguna sebagai penyemangat untuk mengembalikan kejayaan Islam tersebut. Dengan keberanian yang dilandasi ilmu, kekuatan iman, dan keadilan merupakan modal yang besar untuk memulai itu semua. Sesuatu yang besar bermula dari sesuatu yang kecil. Artinya, mimpi-mimpi yang besar bisa kita raih dengan dimulai dengan melakukan hal-hal yang kecil. Tidak ada hal yang remeh dalam kehidupan ini. Oleh sebab itu, dari

23 Hamid Fahmy Zarkasyi, "Peran Sentral Universitas Islam", dalam ISLAMIA: Jurnal Pemikiran dan Peradaban Islam, Vol. III, No. 3, 2008, hal. 12.

24 Andalusia adalah sebuah bintang yang jatuh. Sebuah permata yang runtuh dari mahkota singgasana Islam. Andalusia ibarat sebuah luka yang tak kunjung sembuh, satu-satunya buah hati yang ditangisi sepanjang masa, dan dipuja oleh setiap generasi. Sungguh, ia adalah tragedi yang ratapannnya masih terngiang di telinga dari masa ke masa. Baca Ahmad Mahmud Himayah, Kebangkitan Islam di Andalusia, diterjemahkan dari Al-Andalus Hal Ta'udu?, oleh Sabaruddin, (Jakarta: Gema Insani Press, 2003). Baca juga Wan Mohd Nor Wan Daud, "Iklim Kehidupan Intelektual di Andalusia, Satu Cerminan Islamisasi Dua-Dimensi”, dalam ISLAMIA: Jurnal Pemikiran dan Peradaban Islam, Vol. III, No. 4, 2008, hal. 76-93. Mengenai kejayaan Islam di masa silam, baca juga Bahrul Ulum, "Cordoba, Kota Ilmu pada Masa Silam", dalam ISLAMIA: Jurnal Pemikiran dan Peradaban Islam, Vol. IX, No. 1, 2014, hal. 107-110. pedalaman kita kembalikan kejayaan Islam.

\section{E. Penutup}

Alhasil, masa depan ummatmasa depan Islam di Indonesia adalah tergantung pada kualitas perjuangan ummat Islam itu sendiri. Peradaban ummat-peradaban Islam harus mampu dibangun dan diwujudkan dalam satu bentuk perjuangan dakwah yang cerdas dan ikhlas. Sebab, tantangan terberat ummat saat ini adalah program Westernisasi, terutamanya adalah "proyek" liberalisasi pemikiran Islam, yang terbungkus rapi dalam arus globalisasi-Kolonialisasi. Gerakan ini, selain didukung oleh para cendekiawan Muslim yang telah ter-"Barat"-kan, penyebarannya juga didukung oleh kekuatan "tangan-tangan" global yang memendam sikap islamofobia.

Sebagai penutup, dalam rangka semangat dakwah dan bentuk perjuangan yang cerdas dan ikhlas dalam menghadapi beratnya tantangan yang dihadapi oleh ummat Islam, M. Natsir memberikan nasehatnya:

Tantangan yang ada ini seharusnya tidak mematikan, tetapi bahkan mendorong ummat Islam untuk maju. Dengan kata lain, ada saat-saat ummat Islam diuji untuk meningkatkan mutu, bukan berarti Tuhan benci kepada kita. Apa yang 
menimpa ummat Islam sekarang ini, ialah kita sedang berada dalam periode kristalisasi potensi yang kita miliki. Dalam keadaan demikian, kita jangan mengabaikan apa yang ada di sekeliling kita. ${ }^{25}$

\section{F. Daftar Pustaka}

'Imarah, Muhammad, 1998. Perang Terminologi Islam Versus Barat, diterjemahkan dari Ma'rakatul Mushthalahat baina al-Gharbi wal Islami, oleh Musthalah Maufur, Jakarta: Rabbani Press.

Al Roubaie, Amer, 2005. "Globalisasi dan Posisi Peradaban Islam", dalam ISLAMIA: Jurnal Pemikiran dan Peradaban Islam, Thn. 1, No. 4.

Al-Attas, Syed Muhammad Naquib, 1993. Islam and Secularism, Kuala Lumpur: ISTAC.

Al-Faruqi, Isma'il Raji, 1988. Tauhid, Bandung: Pustaka.

Al-Ghazali, Abu Hamid, t.t. Al-Munqidz min al-Dlalal wa ma'a Kimiya alSa'adah wa al-Qawa'id al-'Asyrah wa al-Adab fi al-Din, Beirut: AlMaktabah Al-Sya'biyah.

2002. Penyelamat Jalan Sesat, diterjemahkan dari Al-Munqidz min al-Dlalal, oleh Nasib Musthafa, Jakarta: Cendekia Sentra Muslim.

Arif, Syamsuddin, 2008. Orientalis dan Diabolisme Pemikiran, Jakarta: Gema Insani Press.

Bachtiar, Tiar Anwar, 2009. "M. Natsir: Pelopor Pendidikan Islam Integral",

25 A. Watik Pratiknya, ed., Percakapan Antar Generasi: Pesan Perjuangan Seorang Bapak (Jakarta: Dewan Dakwah Islamiyah Indonesia: Laboratorium Dakwah, 1989), hal. 45. Baca juga Tiar Anwar Bachtiar, "M. Natsir: Pelopor Pendidikan Islam Integral", dalam ISLAMIA: Jurnal Pemikiran dan Peradaban Islam, Vol. V, No. 1, 2009, hal. 76-89. dalam ISLAMIA: Jurnal Pemikiran dan Peradaban Islam, Vol. V, No. 1.

Daud, Wan Mohd Nor Wan, 2008. "Iklim Kehidupan Intelektual di Andalusia, Satu Cerminan Islamisasi DuaDimensi", dalam ISLAMIA: Jurnal Pemikiran dan Peradaban Islam, Vol. III, No. 4.

Gharisah, Ali, 1989. Wajah Dunia Islam Kontemporer, Puskata Al-Kautsar.

Hardiman, F. Budi, 2004. Filsafat Modern: Dari Machiavelli sampai Nietzsche, Jakarta: Gramedia.

Himayah, Ahmad Mahmud, Kebangkitan Islam di Andalusia, diterjemahkan dari Al-Andalus Hal Ta'udu?, oleh Sabaruddin, (Jakarta: Gema Insani Press, 2003)

Husaini, Adian, 2006. Hegemoni KristenBarat dalam Studi Islam di Perguruan Tinggi, Jakarta: Gema Insani Press.

2005. Wajah

Peradaban Barat: Dari Hegemoni Kristen ke Dominasi SekulerLiberal, Jakarta: Gema Insani Press.

ISLAMIA: Jurnal Pemikiran dan Peradaban Islam, 2008. "Wajah Universitas Islam: Antara Islamisasi dan SekularisasiLiberalisasi", Vol. III, No. 3.

Muslih, Muhammad, 2008. Filsafat IImu: Kajian atas Asumsi Dasar Paradigma dan Kerangka Teori IImu Pengetahuan, Yogyakarta: Belukar.

Nasr, Sayyed Hossein, 1977. Sains dan Peradaban di Dalam Islam, diterjemahkan dari Science and Civilization in islam, oleh J. Mahyudin, Bandung: Pustaka.

Pratiknya, Watik, 1989. Percakapan Antar Generasi: Pesan Perjuangan Seorang Bapak, Jakarta: Dewan Dakwah Islamiyah Indonesia: Laboratorium Dakwah.

Suriasumantri, Jujun S., 2009. Filsafat IImu: Sebuah Pengantar Populer, Jakarta: Pustaka Sinar Harapan. 
Thoha, Anis Malik, 2005. Tren Pluralisme Agama: Tinjauan Kritis, Jakarta: Perspektif.

Ulum, Bahrul, 2014. "Cordoba, Kota IImu pada Masa Silam", dalam ISLAMIA: Jurnal Pemikiran dan Peradaban Islam, Vol. IX, No. 1.

Zarkasyi, Abdullah Syukri, 2011. Bekal untuk Pemimpin, Pengalaman Memimpin Gontor, GontorPonorogo: Trimurti Press.

Zarkasyi, Hamid Fahmy (dkk), 2010. Membangun Peradaban dengan IImu, Depok: Kalam Indonesia.

2012.

"Dakwah", dalam ISLAMIA: Jurnal Pemikiran dan Peradaban Islam, Vol. VII, No. 2.

2014. "Peran Masjid dalam Pendidikan Karakter (Akhlaq)", dalam ISLAMIA: Jurnal Pemikiran dan Peradaban Islam, Vol. IX, No. 1. , 2008. "Peran Sentral Universitas Islam", dalam ISLAMIA: Jurnal Pemikiran dan Peradaban Islam, Vol. III, No. 3.

2008.

Liberalisasi Pemikiran Islam (Gerakan bersama Missionaris, Orientalis dan Kolonialis), GontorPonorogo: CIOS.

2012. Misykat; Refleksi tentang Westernisasi, Liberalisasi, dan Islam, Jakarta: INSISTS \& MIUMI.

2010.

Peradaban Islam: Makna dan Strategi Pembangunannya, Gontor Ponorogo: CIOS. 